\title{
Distance education MBA students: an investigation into the use of an orientation course to address academic and social integration issues
}

\author{
Heather Kanuka* and Kam Jugdev \\ Athabasca University, Canada
}

\begin{abstract}
Distance education programmes warrant the use of innovative intervention practices to enhance student learning experiences. Academic and social empathy by faculty has been shown to enhance student retention in programmes along with their critical thinking abilities. Using Holmberg's theory of teaching-learning conversations as the guiding theoretical framework, the purpose of this study was to assess whether an intervention activity (a one-week orientation course) increases academic and social empathy for students entering a distance-delivered MBA programme. Empathy was measured through seven academic and social integration indicators. Using pre-surveys and post-surveys $(n=102)$, the results reveal that an orientation intervention can be effective for facilitating social and academic empathy.
\end{abstract}

Keywords: Distance education; $M B A$ programmes; Orientation activities; Social and academic empathy

\section{Introduction}

Helping prepare graduates for managerial and leadership positions, Masters of Business Administration (MBA) programmes originated at the turn of the last century with the aims of emphasising specialised vocational training and broad generalist issues (BubnaLitic \& Benn, 2003). These programmes experienced a groundswell of support in the 1960s, and currently MBAs are a global phenomenon (Bubna-Litic \& Benn, 2003). The demand for MBA programmes continues to grow in North America (Na Ubon, 2002), Asia, the United Kingdom and Europe (with England leading the charge).

\footnotetext{
*Corresponding author. Athabasca University, 33410030107 Street, Edmonton, Alberta, Canada T5J 3E4. Email: heatherk@athabascau.ca
} 
As international competition in the MBA market mounts, universities continue to assess and modify programme content and methods of delivery. Some universities are embarking on niche MBA programmes, others are collaborating with partner universities to deliver joint programmes, some are reducing the length of their programmes, while some are forging stronger alliances with businesses (McClenahen et al., 1995). Others are delivering their MBAs in innovative ways, such as distance-delivery methods that use Internet learning management systems (e.g. WebCT ${ }^{\mathbb{R}}$, Blackboard $^{\circledR}$, Lotus Notes ${ }^{\circledR}$, First Class ${ }^{\circledR}$ ) - most often referred to as 'online MBAs.' In the United States alone, for example, $51 \%$ of the online MBA programmes were launched in the past five years (Na Ubon, 2002) and 2.5\% of MBA programmes are online (Bocchi et al., 2004).

Online MBA programmes can be categorised in the following four ways: self-paced independent study, asynchronous and paced interactive learning, synchronous and paced learning, and a combination of online and in-person paced learning (Bocchi et al., 2004). There are many advantages to online programmes, with the primary benefit revolving around the notions of convenience and flexibility, or 'anytime/ anywhere learning.' Online MBAs are particularly convenient and advantageous for mature students who work full time and cannot afford to leave their jobs (Bocchi et $a l ., 2004)$. More recently, greater numbers of employers are also supporting distancedelivered MBAs for reasons associated not only with cost and flexibility, but with the belief that distance-learning programmes are more practical than traditional campusbased programmes. Of particular interest to employers is the ability of their employees to be involved in research projects within their own organisation-which directly benefits the employer (TEIUL, 2005).

However, the quality of online programmes has been and continues to be debated. Much research has been conducted over the past two decades to resolve this debate, and results have shown that distance delivery can be equal to or more effective than classroom delivery (Bocchi et al., 2004). Most recently, an extensive meta-analysis conducted by Bernard et al. (2004) revealed that many applications of distance education outperform their classroom counterparts. Supporters of online programmes have argued that online distance learning is superior to face-to-face learning because students in the online classroom are assessed based on their ability to communicate in a text-based environment and, therefore, are forced to demonstrate an understanding of material in ways that go beyond the closed-book tests that typically characterise the face-to-face classroom (Bocchi et al., 2004). Other supporters of online programmes have reasoned that text-based Internet communication tools facilitate the development of argument formation capabilities, improve written communication skills, support greater complex-problem-solving abilities and increase opportunities for reflective deliberation (Abrami \& Bures, 1996; Garrison et al., 2001; Hawkes, 2001).

While these espoused benefits of online learning should not be underestimated, the tracking of mature learners (learners in the United Kingdom over the age of 25) reveals they are twice as likely to leave their programme of study prior to completion than are younger, traditional, and on-campus learners (18-21 years of age) 
(McGivney, 2004). Few details on international withdrawal patterns are available; however, aggregated data on completion rates within specific regions are available. For example, in 1998 the Distance Education and Training Council in the United States surveyed 61 member institutions and found the average non-start rate for mature learners was $16 \%$, the average rate for completing a course was $57 \%$ and the average graduation rate was 38\% (Distance Education and Training Council, 1998). Online MBA courses have also been linked with higher withdrawal rates than classroom courses or combination courses ( $8 \%$ of men and $6 \%$ of women withdraw from online courses) (Bocchi et al., 2004).

The higher attrition rates associated with online programmes have been attributed in part to the difficulty of adjusting to a self-directed approach, finding the courses more rigorous than expected, and a lack of experience with online learning (Bocchi et al., 2004). Prior literature has also revealed that isolation is a problem for distance learners (Collett et al., 1999). Compounding these problems, mature learners also typically re-enter academic studies with high levels of tension and anxiety (Brookfield, 1986; Taylor et al., 2000; Moore \& Kearsley, 2005). How best to prepare learners for the rigour of a distance-delivered online MBA, as well as reduce high levels of tension, anxiety, and feelings of isolation - which are factors that contribute to attrition - is not yet well understood. The aim of this study was to extend understandings of how to help mature learners adjust to online and distance education environments to achieve successful programme completion.

\section{Guiding theoretical framework: Holmberg's theory of teaching-learning conversations}

Non-completion rates in distance-learning and open-learning studies are a complex set of issues that include internal and external factors. With regard to external factors, research has revealed that elements such as family/partner support, financial status and gender all influence completion rates (Moore \& Kearsley, 2005) - factors that are beyond institutions' ability to control and/or change. However, other issues affecting completion rates are not beyond institutions' influence. Such elements include the perceived satisfaction with and value of the courses and/or programme, academic skill sets, collegial interaction and camaraderie, and a sense of belonging to the institution (McGivney, 2004). It has been theorised by Holmberg (see, for example, Holmberg, $1983,1997,1999,2001)$ that empathy, which encompasses many of these issues, is the optimal condition for the facilitation of effective learning and student-tutor/ teacher interaction.

Research conducted on empathy by Holmberg has revealed that the more conversations (e.g. mediated interactions via email, computer-mediated communication, telephone), the greater the students' perceptions of institutional support-the greater the students' interest in making the subject matter personally relevant. In turn, the greater the students' perceived personal relevance of the subject matter, the greater the motivation and the more effective the learning is that occurs (Holmberg, 1983, 2001; Holmberg et al., 1982). 
The critical aspects of this theory include a focus on the relevance of programme material to the student, emotional involvement, ease of communication, and frequent and timely interaction. Relevance of the subject matter to the students results in their increased ability to accommodate new knowledge and solutions into existing cognitive structures. Emotional involvement leads to a stronger emphasis on the development of rapport between and among students, the institution and tutors and/or teachers. Holmberg maintains that when these elements are present in the distancelearning process, an increase in motivation, learning pleasure and successful programme completion results. It should be noted that Holmberg's theory of teaching-learning conversations has been criticised for keeping students in their comfort zones and inhibiting the development of self-directed and self-regulatory skills. Peters (1998), for example, maintains that Holmberg's conversational style results in overprotecting the students and preventing them from confronting the complexity of all that academia entails. The concept of empathy, however, has also been identified as an important element in the instructor's (or tutor's) ability to facilitate critical thinking. In an extensive review of the literature on critical thinking by ten Dam and Volman (2004), it is noted that 'Elements such as care, empathy, and involvement are ... important aspects of the learning community in which students learn to think critically' (p. 374).

\section{Need for the study}

Prior literature has suggested that intervention activities (i.e. orientation courses) for mature students entering into new programmes of study can address many of the issues already cited (Collett et al., 1999; Kanuka, 2001), as well as facilitate the kind of empathy that Holmberg proposes is the essential guiding principle for effective distance-learning experiences. We know, for example, that certain kinds of motivational factors (i.e. career goals and objectives) are important determiners of success (Moore \& Kearsley, 2005). Activities in orientation courses cited in the literature as effective for increasing motivation are academic and social integration. Academic integration encompasses the ability to integrate studying with other daily activities, whereas social integration is the ability to interact with teachers and/or tutors and other students (Picciano, 2001). It has been suggested further by Picciano that distance-education facilitators have a responsibility to provide learning environments that will maximise the factors that contribute to successful programme completion and will minimise factors that contribute to attrition.

Within the online distance-education literature, there is an absence of research literature on the use of intervention activities, such as orientation courses, the aim of which is to facilitate empathy as is described by Holmberg (2001). The purpose of this study was to explore this gap in the research literature. Using pre and post opinion surveys for an MBA orientation course, the objective of this study was to examine levels of empathy before and after an orientation programme for mature learners entering an MBA programme in an open-learning and distance-learning institution that uses text-based asynchronous learning management systems as the primary 
means of course delivery and communication. Based on Holmberg's theory of teaching-learning conversations, the overarching aim of the MBA orientation (Masters of Business Administration Orientation [MBAO]) was to increase perceived levels of academic and social empathy.

\section{Literature review: mature distance-education learners}

Mature learners who resume formal learning activities in open-learning and distancelearning environments may require more comprehensive support structures than mature learners in on-campus and conventional settings (Moore \& Kearsley, 2005). Without support structures, mature learners in open-learning and distance-learning environments are at risk for programme non-completion. Frequently cited reasons for programme non-completion within open-learning and distance-learning environments include the poor quality of the learners' experience and social environment (Yorke, 1999), and the lack of 'pull' factors that are available in on-campus environments but absent from open-learning and distance-learning environments (such as social activities and scheduled class meetings) (McGivney, 2004). Academic difficulties, such as adjusting to the rigours of academia, are another concern (Carr et al., 1996; Davis \& Elias, 2003). Other reasons cited for increased support structures are varied, with the most commonly cited reason for programme non-completion being competing commitments (i.e. family and work) (Kember, 1989; Anderson \& Kanuka, 1997; Kanuka, 2001). Research has revealed that non-completion is typically not the result of a single cause, but an accumulation of a number of causes (Moore \& Kearsley, 2005).

It has been suggested that successful programme completion for mature learners could be increased if social and academic integration activities were provided. Such activities, for example, might include access to programme details, such as specifics on the course content, required time commitment and related information on necessary academic skill sets. This type of information is often not provided by distance education providers (McGivney, 2004), yet it is the access to, and the knowledge of, this information that makes it possible for learners who have competing commitments to understand what is necessary for successful programme completion. In a study conducted by Yorke and Thomas (2003), the presence of the following was identified as overcoming non-completion challenges:

- An institutional climate supportive in various ways of students' development, that was perceived as 'friendly';

- An emphasis on support leading up to, and during, the critically important first year of study;

- An emphasis on formative assessment in the early phase of programmes;

- A recognition of the importance of the social dimension in learning activities; and

- A recognition that the pattern of students' engagement in higher education was changing, and the preparedness to respond positively to this in various ways. (Yorke \& Thomas, 2003, p. 22) 
To be successful in a distance-delivered higher education environment, learners need to be self-disciplined, have initiative, motivation, commitment, time management skills and organisational skills (Collett et al., 1999). Since many students are juggling classes, work, family and travel commitments, they either require excellent time management skills at the onset or a quick review to help them develop routines that work well for them. Distance-delivered online programmes also require that students have good computer skills because computer communication technologies are used (e.g. Internet text-based asynchronous learning management systems) that often involve special software, multimedia and general software (Kathawala et al., 2002). And of particular importance in higher education settings, students must be able to express themselves well in writing - and to do so in an academic style, which is quite different from the business style that most mature adults entering into MBA programmes use in their business correspondence.

Some literature on these issues exists that indicates academic and social integration fostered by programme facilitators of distance learning can help mature learners adjust to the demands of higher education. In particular, Tinto's (1993) model shows how academic integration can help students accommodate the requirements of a programme of study, an element that also develops the students' social integration. For example, the use of cohort groups to foster camaraderie, as well as group exercises that emphasise the sameness among students rather than differences, can foster the development of academic and social integration (Na Ubon, 2002). Hence institutions, to some degree, have the ability to influence how students are integrated academically and socially. In turn, these experiences can result in mature students' commitment to successful programme completion.

Other literature has also supported this assertion. For example, Bean and Eaton (2000) maintain, similar to Tinto, that learners interact with the institution both academically and socially. These interactions can, and do, influence the learners' commitment to the institution, which, in turn, influences completion rates. Alternatively, when learners do not experience academic and social integration (or do not acquire a sense of institutional 'belongingness'), they have a greater likelihood of withdrawing prior to programme completion. Other literature (for example, Berger, 2000; Thomas, 2002) concurs there is an association between programme completion and an institution's efforts to create academic and social integration-or the extent to which students perceive they belong in the institution.

More recently, the literature on social and academic integration has been expanded. Yorke (2004), for example, has argued further that the social dimension is of particular importance to mature learners who have existing external obligations, such as work and family. These existing commitments preclude many mature learners from participating in academic social functions. As such, 'it becomes important for institutions to think about how the academic experiences they provide might have a "social" dimension - which could imply some, perhaps quite radical, changes in pedagogy' (Yorke, 2004, p. 26). Given the logic of this argument, it stands to reason that providers of open and distance learning should focus on both the academic and the social integration of their learners, and explore how to create positive and 
pedagogically creative academic communities. However, how best to achieve this remains a challenge - a challenge that is not well understood (Mentknowski, 2000; Read et al., 2003). This has been identified as a worthwhile topic for further study (Yorke, 2004). It is possible that the application of Holmberg's theory on teachinglearning conversations, whereby empathy is the guiding principle, could be effective for achieving both the social and academic dimensions necessary for successful distance education experiences.

\section{Background to the study}

On average, the MBA students at Athabasca University are 40 years old and have approximately nine years of management experience. Typical of mature learners, the students embarking on the distance education MBA programme face the breadth of non-completion challenges in the forms of new technology, learning platforms, university processes and apprehensions about time management, organisational skills - as well as learning how to effectively engage in technology mediated conversations. Data from four recent intakes of students $(n=205)$ showed that $38.5 \%$ of the students took up to six months from the time they started to research MBA programmes to submit an application to Athabasca University, and $28.3 \%$ took up to one year. This estimate indicates that about one-third of the students took up to a year to make their decision to start their MBA programme, which suggests this undertaking is perceived to be a major investment on their part.

The MBAO was established several years ago to help mature learners overcome many of the challenges they face entering a new programme of study. As mature learners, many have been away from academic courses for a number of years and are often apprehensive about their ability to learn and keep up, particularly since most also have jobs and family commitments. Many programme participants face the added challenge of learning how to use Internet learning management communication tools (e.g. Lotus Notes ${ }^{\circledR}$ ). Related to this point, many of the students have never engaged in online course discussions in a text-based asynchronous manner and experience feelings that range from anxiety to fear. Overcoming these feelings can take time, in part because they do not 'see' their fellow students or teaching staff. Consequently, the MBAO was established as a programme of welcome into a friendly and caring environment that also assists new programme participants to become familiar with the academic culture and the institutional environment-providing what Holmberg (2001) refers to as empathy, or more precisely, academic and social empathy.

Upon acceptance to the MBA Programme, students receive a letter from the Dean welcoming them to the programme and introducing them to their first course, the MBAO. Although students are not graded on the MBAO, they are informed in this letter that it is a required course. The MBAO (delivered one week prior to the programme coursework) introduces new students to the MBA programme's technology-mediated learning system (Lotus Notes ${ }^{\circledR}$ ). Social integration is provided by introducing students to the online discussion databases in a friendly and caring 
manner-an introduction that identifies techniques to help them engage in effective conversations with their course colleagues and teaching staff. In an effort to familiarise students with Lotus Notes ${ }^{\circledR}$, the MBAO mirrors the format of the typical eightweek academic courses offered in the programme. For example, the MBAO provides a work plan for the week that informs students what activities they should undertake on a daily basis. In addition, students complete and submit assignments online for which they receive academic feedback. On the social side, course participants are also given opportunities to practice participating in conversations using Lotus Notes ${ }^{\circledR}$ group conferencing tools. An academic coach (who is a graduate of the MBA programme) facilitates the MBAO.

In addition, each year feedback is solicited from graduating MBA students about the programme; several questions ask them for their advice to incoming students. In 2003, the survey data were manually coded and the descriptive feedback from more than 100 students was analysed. The analysis resulted in the identification of the following key themes in advice offered by alumni to new students:

- Time management: develop effective study skills, learn how to pace oneself, adhere to the course work plan, and do not under estimate how long some of the activities/ assignments may take.

- Learning: much of what is learned comes from participating in the conversations regularly, applying concepts at work, and sharing experiences with fellow students.

- The team: develop a network of friends in the programme and ask for help as needed.

- Your life: completing the MBA requires even more balance between work, home life and a social life.

Based on the main themes elicited from recent alumni feedback, it was deemed important to ask questions about how comfortable new students were with making meaningful contributions to the conversations, participating in online conversations, team building and effective time management skills. Emphasis on these topics was also influenced by faculty input regarding the topics they deemed relevant for new incoming students.

\section{Method}

This study addressed the following question: Is there a significant difference in student empathy levels before and after the MBAO? The theoretical framework guiding this study was Holmberg's (2001) theory of teaching-learning conversations. The critical aspect of this theory is empathy, which, when present in the distance-learning environment, provides a stronger focus on relevance, emotional involvement, ease of communication, and frequent and undelayed interaction.

Seven constructs comprising academic and social aspects of empathy were identified based on graduating student feedback and current research on non-completion rates for mature learners. Following were the hypotheses tested as the indicators of academic and social empathy: 
- After the MBAO:

- students will be less apprehensive about using Lotus Notes ${ }^{\circledR}$;

- students will be less concerned about being able to make a meaningful contribution;

- students will be less concerned about effective time management;

- students will be less concerned about participating in an online discussion;

- students will have a better understanding of the difference between business and academic writing;

- students will have a better understanding of how to cite a reference source properly; and

- students will have a better understanding of how an online course works.

\section{Study design}

The MBAO survey consisted of the seven empathy indicators in a questionnaire format using a five-point Likert-type scale with the anchors being 'strongly agree' and 'strongly disagree' (see Table 1). The survey was hosted at Zoomerang ${ }^{\mathbb{B}}$, which is an Internet-based software provided by Market Tools Inc ${ }^{\circledR}$. On average, the survey took five minutes to complete. After piloting the instrument for two intakes in 2003 to address validity and reliability issues, minor modifications were made in 2004 and further data were gathered for the May $2004(n=44)$ and October $2004(n=58)$ intakes. This paper is based on the consolidated results for these two intakes $(n=$ 102). We believe pooling of the results is justified because in both intakes the students were new MBA students that represented a demographically homogeneous group.

Table 1. Pre survey and post survey

\section{Question Construct}

1
Pre survey: I am apprehensive about using the Lotus Notes technology Post survey: I am less apprehensive about using the Lotus Notes technology Pre survey: I am concerned about being able to make a meaningful contribution Post survey: I am less concerned about being able to make a meaningful contribution Pre survey: I am concerned about effective time management Post survey: I am less concerned about effective time management Pre survey: I am concerned about participating in an online discussion Post survey: I am less concerned about participating in an online discussion Pre survey: I do not fully understand the difference between business and academic writing

Post survey: I have a better understanding of the difference between business and academic writing

Pre survey: I do not know how to cite a reference source properly (e.g. book, paper, online source)

Post survey: I am starting to understand how to cite a reference source properly (e.g. book, paper, online source)

Pre survey: I do not understand how an online course works

Post survey: I have a better understanding of how an online course works 
On the fourth day of the five-day MBAO, using a group distribution email address that provided anonymity, the students were sent a URL link to the survey and invited to participate. In the email, it was explained that we were interested in their opinions and that their input would help to improve the MBAO and better meet future student needs. To improve response rates, follow-up reminders were sent to the MBAO students a week later, thanking them for completing the survey and reminding them to do so if they had not yet completed it.

\section{Results}

The survey was sent to new students enrolled in the MBA programme in May 2004 and in October 2004. In May 2004 there were 62 students registered; 44 completed the survey, for a response rate of $71.0 \%$. In October 2004 there were 92 students registered; 58 completed the survey, for a response rate of $63.0 \%$. In total, 102 students completed the MBAO survey out of 154, for an overall response rate of $66.2 \%$. Within the sample of 102 students, $62(60.8 \%)$ were male and $40(39.2 \%)$ were female; the average age was 40 . This sample was representative of the MBA student demographics.

Factor analysis was performed on the seven questions of 'before' (pre test) by Principal Component Extraction with varimax rotation. The results indicate that there are three factors, grouping of the questions and their corresponding factor loadings of which are: factor 1, academic, Q5 (0.66), Q6 (0.85), Q7 (0.68); factor 2, participation, Q3 (0.82), Q4 (0.79); and factor 3, technology, Q1 (0.87), Q2 (0.61).

Subscales (academic, participation and technology) of the pre test were created by the sum of their corresponding grouping of questions, and for the post test by summing the corresponding grouping of reverse coded questions. Total scores of the pre test and the post test were also created by summing all seven pre-test questions and the sum of all seven post-test questions (with the appropriate reverse coding). Table 2 indicates that there is a statistically significant difference between the pre test

Table 2. Results for the subscales of the May 2004 and October 2004 intakes $(n=102)$

\begin{tabular}{|c|c|c|c|c|c|c|c|}
\hline & \multicolumn{2}{|c|}{ Before } & \multicolumn{2}{|c|}{ After } & \multirow[b]{2}{*}{$t$} & \multirow[b]{2}{*}{$\begin{array}{l}\text { Degrees of } \\
\text { freedom }\end{array}$} & \multirow[b]{2}{*}{$p$ value } \\
\hline & Mean & $\begin{array}{l}\text { Standard } \\
\text { deviation }\end{array}$ & Mean & $\begin{array}{l}\text { Standard } \\
\text { deviation }\end{array}$ & & & \\
\hline Academic & 8.13 & 2.61 & 11.93 & 1.54 & -12.15 & 101 & $<0.001^{\star}$ \\
\hline Participation & 5.02 & 1.85 & 7.11 & 1.51 & -8.68 & 101 & $<0.001^{\star}$ \\
\hline Technology & 5.73 & 2.05 & 7.93 & 1.37 & -8.56 & 101 & $<0.001^{\star}$ \\
\hline Total & 18.87 & 4.74 & 26.97 & 3.74 & -12.52 & 101 & $<0.001^{\star}$ \\
\hline
\end{tabular}

${ }^{\star}$ Significant at alpha $=0.05$.

Note: calculated statistics of 'Post' scores are based on reversed coding because of the wording used in the pre and post questions; for example, Pre survey: I am apprehensive about using the Lotus Notes technology; Post survey: I am less apprehensive about using the Lotus Notes technology. 
Table 3. Results of the one-sample $t$-test

\begin{tabular}{|c|c|c|c|c|c|c|c|c|}
\hline \multirow[b]{2}{*}{$\begin{array}{l}\text { Item and } \\
\text { subscale }\end{array}$} & \multicolumn{4}{|c|}{ Before } & \multicolumn{4}{|c|}{ After } \\
\hline & Mean & $\begin{array}{l}\text { Standard } \\
\text { deviation }\end{array}$ & $t(101)$ & $\begin{array}{l}\text { One-tailed } \\
\text { significance }\end{array}$ & Mean & $\begin{array}{l}\text { Standard } \\
\text { deviation }\end{array}$ & $t(101)$ & $\begin{array}{l}\text { One-tailed } \\
\text { significance }\end{array}$ \\
\hline 1 & 2.95 & 1.38 & -3.58 & 0.361 & 4.07 & 0.88 & 12.24 & $<0.001^{\star}$ \\
\hline 2 & 2.77 & 1.06 & -2.15 & $0.017^{\star}$ & 3.86 & 0.73 & 11.91 & $<0.001^{\star}$ \\
\hline 3 & 2.23 & 1.13 & -6.90 & $<0.001^{\star}$ & 3.29 & 0.95 & 3.13 & $0.001^{\star}$ \\
\hline 4 & 2.79 & 1.07 & -1.95 & $0.027^{\star}$ & 3.81 & 0.85 & 9.64 & $<0.001^{\star}$ \\
\hline 5 & 2.95 & 1.08 & -0.46 & 0.325 & 3.78 & 0.79 & 10.01 & $<0.001^{\star}$ \\
\hline 6 & 2.46 & 1.18 & -4.60 & $<0.001^{\star}$ & 4.06 & 0.61 & 17.52 & $<0.001^{\star}$ \\
\hline 7 & 2.72 & 1.21 & -2.38 & $0.010^{\star}$ & 4.09 & 0.72 & 15.29 & $<0.001^{\star}$ \\
\hline Academic & 8.13 & 2.61 & -3.38 & $0.001^{\star}$ & 11.93 & 1.54 & 19.19 & $<0.001$ \\
\hline Participation & 5.02 & 1.85 & -5.35 & $<0.001^{\star}$ & 7.11 & 1.51 & 7.39 & $<0.001^{\star}$ \\
\hline Technology & 5.73 & 2.05 & -1.36 & 0.089 & 7.93 & 1.37 & 14.20 & $<0.001^{\star}$ \\
\hline Total & 18.87 & 4.74 & -4.54 & $<0.001^{\star}$ & 26.97 & 3.74 & 16.13 & $<0.001^{\star}$ \\
\hline
\end{tabular}

$\star$ Significant at alpha $=0.05$.

(before) and post test (after) on each of all the subscales and total scores. Hence, all the variables investigated showed an improvement from before the MBAO to after the MBAO.

One-sample $t$-tests were performed for each question, subscales and total scores with their corresponding midpoints for 'Before' (pre test) and 'After' (post test). Since we used a five-point scale, the midpoint for each question was 3.0. For the subscales, since 'academic' consisted of three items, the ranges of this score were from 3 to 15 , with a midpoint of 9.0. The subscales 'participation' and 'technology' consisted of two items each, so the ranges of their scores were from 2 to 10 , with a midpoint of 6.0. The midpoint for the total scale was 21.0 since there are seven items and the ranges of the scores go from 7 to 35 .

Table 3 indicates that for the pre test ('Before'), all items (except Q1, Q5), all subscales (except technology) and the totals are statistically significantly lower than their corresponding midpoints. However, Table 3 indicates that for the post test ('After'), all items, subscales and total scores are all statistically significantly higher than their corresponding midpoints.

\section{Limitations}

A limitation of this study is that we did not gather complete demographic data in 2004 (e.g. age, gender, industry) but we are doing so for 2005 intakes. Another limitation is that we surveyed the students once to gather pre-MBAO and post-MBAO data (to avoid survey fatigue) instead of structuring the study to gather this information twice (e.g. a week before the MBAO and a week after, or assessing students after the first course). We used only single items for each construct when ideally we should have a 
minimum of three items per construct. For this reason, we did the factor analysis that grouped the constructs. This study was also limited to students who volunteered to respond to the survey. It is possible, therefore, that some bias exists because students who participate in research are often the most dedicated. These limitations influence the degree to which the results of this study can be generalised to other mature students enrolled in distance-delivered MBA programmes.

\section{Discussion}

The aim of this study was to explore the impact of an intervention activity (the MBAO). Based on the seven constructs identified as facilitating social and academic empathy, the results of this study reveal that such intervention programmes can be effective. Specifically, this intervention (the MBAO) increased confidence, academic skill development (e.g. academic writing skills, academic referencing, using online library services), effective time management skills and the development of technology skill sets that promote and support successful participation in online learning environments (text-based asynchronous learning management fora tools). This was most evident in the results to the question in the survey where 98/102 students $(96.1 \%)$ strongly agreed that 'Having completed the Orientation Week, I feel more comfortable starting the MBA programme than I would have without the orientation.' In agreement with the literature by Moore and Kearsley (2005) and Eastmond (1998), the provision of creative and empathic student services is one facet of the distance-learning experience with which the institution can make a significant impact.

Intervention activities can also provide empathetic social and academic exchanges that can result in the reduction of anxiety and tension. Most well-designed distancedelivered programmes are sensitive to these needs and help students from falling behind by providing caring and friendly student support services to assist students who experience difficulties. Simpson (2004) argues further that student support services should be more than reactive to students experiencing difficulties (e.g. through the provision of intervention programmes). When institutions only react to students who ask for help, students that do not ask for help may be at greater risk of dropping out.

\section{Further research}

While the results of this study are encouraging, further research following students to programme completion is required. In particular, further research is needed to assess the impact of the MBAO on programme completion and on whether or not intervention programmes, such as the MBAO, are sufficient to instil a sense of students' belonging to the institution. For example, based on feedback from present and past programme students, the use of Lotus Notes ${ }^{\circledR}$, selected primarily for its asynchronous strengths, we are discovering it is not sufficient for facilitating social integration. Increasingly, we are finding that new students are interested in using, and are requesting, the options of synchronous learning tools such as video conferencing, Internet 
audio conferencing and MSN Messenger ${ }^{\circledR}$. We are currently examining different technologies and tools to incorporate into our learning management system.

We also are currently working on a tailored peer-to-peer mentoring programme whereby we pair a new student (who is experiencing feelings of being lost and isolated) with an alumnus of the programme. We think that a short-term, peer-topeer mentoring relationship can further help minimise new student anxieties related to academic and social integration issues.

\section{References}

Abrami, P. C. \& Bures, E. M. (1996) Computer-supported collaborative learning and distance education, American fournal of Distance Education, 10(2), 37-42.

Anderson, T. \& Kanuka, H. (1997) New platforms for professional development and group collaboration. Available online at: www.ascusc.org/jcmc/vol3/issue3/anderson.html (accessed 3 February 2005).

Bean, J. P. \& Eaton, S. B. (2000) A psychological model of college student retention, in: J. M. Braxton (Ed.) Reworking the student departure puzzle (Nashville, TN, Vanderbilt University Press), 48-61.

Berger, J. B. (2000) Optimizing capital, social reproduction, and undergraduate persistence, in: J. M. Braxton (Ed.) Reworking the student departure puzzle (Nashville, TN, Vanderbilt University Press), 95-124.

Bernard, R. M., Abrami, P. C., Lou, Y., Borokhovski, E., Wade, A., Wozney, L., Wallet, P. A., Fiset, M. \& Huang, B. (2004) How does distance education compare with classroom instruction? A meta-analysis of the empirical literature, Review of Educational Research, 74(3), 379-439.

Bocchi, J., Eastman, J. K. \& Owens-Swift, C. (2004) Retaining the online learner: profile of students in an online MBA program and implications for teaching them, fournal of Education for Business, 79(4), 245-253.

Brookfield, S. D. (1986) Understanding and facilitating adult learning (San Francisco, CA, JosseyBass).

Bubna-Litic, D. \& Benn, S. (2003) The MBA at the crossroads: design issues for the future, Fournal of the Australian and New Zealand Academy of Management, 9(3), 25-36.

Carr, K. C., Fullerton, J. T., Severino, R. \& McHugh, M. K. (1996) Barriers to completion of a nurse-midwifery distance education program, fournal of Distance Education, 11(1), 111-131.

Collett, D., Kanuka, H., Blanchette, J. \& Goodale, C. (1999) Learning technologies in distance education (Edmonton, University of Alberta).

Davis, R. \& Elias, P. (2003) Dropping out: A study of early leavers from higher education. Research Report No. RR386 (London, Department for Education and Skills).

Distance Education and Training Council (1998) Survey of member institutions (Washington, DC, Michael Moore).

Eastmond, D. V. (1998) Adult learners and Internet-based distance education, in: B. Cahoon (Ed.) New directions for adult and continuing education (San Francisco, CA, Jossey-Bass), 33-41.

Garrison, D. R., Anderson, T. \& Archer, W. (2001) Critical thinking, cognitive presence and computer conferencing in distance education, American fournal of Distance Education, 15(1), 7-23.

Hawkes, M. (2001) Variables of interest in exploring the reflective outcomes of network-based communication, Fournal of Research on Computing in Education, 33(3), 299-315.

Holmberg, B. (1983) Guided didactic conversation, in: D. Seward, D. Keegan \& B. Holmberg (Eds) Distance education: international perspective (London, Croom Helm).

Holmberg, B. (1997) Distance-education theory again, Open Learning, 12(1), 31-39. 
Holmberg, B. (1999) The conversational approach to distance education, Open Learning, 14(3), $58-60$.

Holmberg, B. (2001). Distance education in essence. An overview of theory and practice in the early twenty-first century (Oldenburg, Germany, Bibliotheks-und Informationssytem der Universität Oldenburg).

Holmberg, B., Schuemer, R. \& Obermeier, A. (1982) Sur Effizienz des gelenkten didaktischen Gespräches. ZZIF-Projekt 2.6, Schulssbericht mit einer englischen Zusammenfassung [with an English summary] (Hagen, FernUniversität).

Kanuka, H. (2001) University student perceptions of the use of the web in distance-delivered programmes, The Canadian fournal of Higher Education, 31(3), 49-72.

Kathawala, Y., Abdou, K. \& Elmuti, D. S. (2002) The global MBA: a comparative assessment for its future, Fournal of European Industrial Training, 26(1), 14-23.

Kember, D. (1989) A longitudinal-process model of drop-out from distance education, fournal of Higher Education, 60(3), 278-301.

McClenahen, J. S., Bredin, J. \& Clark, T. (1995) The MBA: where in the world is it headed?, Industry Week, 43-51.

McGivney, V. (2004) Understanding persistence in adult learning, Open Learning, 19(1), 33-46.

Mentknowski, M. (2000) Learning that lasts: integrating learning, development, and performance in college and beyond (San Francisco, CA, Jossey-Bass).

Moore, M. \& Kearsley, G. (2005) Distance education: a systems view (2nd edn) (Belmont, CA, Thompson Wadsworth).

Na Ubon, A. (2002) A report on distance MBA programs (Toronto, York University).

Peters, O. (1998) Learning and teaching in distance education: analyses and interpretations from an international perspective (London, Kogan Page).

Picciano, A. G. (2001) Distance learning. Making connections across virtual space and time (Upper Saddle River, NJ, Prentice-Hall).

Read, B., Archer, L. \& Leathwood, C. (2003) Challenging cultures? Student conceptions of 'belonging' and 'isolation' at a post-1992 university, Studies in Higher Education, 28(3), 261-277.

Simpson, O. (2004) The impact on retention of interventions to support distance learning students, Open Learning, 19(1), 79-95.

Taylor, K., Marinearu, C. \& Fiddler, M. (2000) Developing adult learners (San Francisco, CA, Jossey-Bass Publishers).

TEIUL. (2005) Which MBA online? Available online at: http://mba.eiu.com/index.asp (accessed 15 March 2005).

ten Dam, G. \& Volman, M. (2004) Critical thinking as citizenship competence: teaching strategies, Learning and Instruction, 42(4), 359-379.

Thomas, E. (2002) Student retention in higher education: the role of institutional habitus, fournal of Education Policy, 17(4), 423-442.

Tinto, V. (1993) Leaving college: rethinking the causes and cures of student attrition (2nd edn) (Chicago, IL, University of Chicago Press).

Yorke, M. (1999) Leaving early: undergraduate non-completion in higher education (London, Falmer Press).

Yorke, M. (2004) Retention, persistence and success in on-campus higher education, and their enhancement in open and distance learning, Open Learning, 19(1), 19-32.

Yorke, M. \& Thomas, L. (2003) Improving the retention of students from lower socio-economic groups, fournal of Higher Education Policy and Management, 25(1), 63-74. 